\title{
Mass Media and Re-Branding Nigeria Project: A Historical Evaluation of a Failed Government Policy
}

ANI, Kelechi Johnmary

\section{Abstract}

M ass media exercise extra-ordinary influence on the state and citizenry of every country and the ability of media to facilitate man's behavioural change through its agenda- setting role makes them central in the re-branding process. The implication became that those politicians who champion the re-branding process tried to win the citizenry's legitimacy through the media. This paper shows that the major challenges of the rebranding project include the inability of the Nigerian political leadership to rebrand themselves, corruption in every sphere of our national life, national insecurity, advance fee fraud, collapse of the education sector, poverty. It revealed that peace is a multi-dimensional term, which creates new environment for progressive nation building process. The rebranding project finally failed when the protagonist minister went to contest for senatorial election and his successor refused to step into her re-branding project shoes. This work called for the rise of a new government and media that would engage in ethical politics through sound leaders, priming, peace building, ethical education, etc as the roadmap to sustainable peace, security and national re-branding. The paper concluded by showing that it is only a national rebranding that is championed by the masses which can lead the citizenry to the desired goals of being a real Giant of Africa.

Keywords: Kidnapping, Mass Media, Re-branding Process, Corruption, National Branding, Nigeria. 


\section{Introduction}

The multi-media systems are powerful agents of change and social re-orientation in the present globalized world. They not only instruct the citizenry on the ethical norms and values needed for societal change but also bring about changes capable of transforming the citizens. They are source of information to all and on a given society as well on how to promote societal building. They function as agent of social re-orientation and behavioural change. They are the 'torch' through which many of the citizenry see and the 'mouth' through which the politicians speak. They do not only enhance the legitimacy of societal norms but they also criticize the ills that crippled societal growth. They promote the institutionalization of positive behaviour amongst the citizenry. They are central in the societal re-branding process. The push for national re-branding enters a country when there are numerous assumed un-ethical societal behaviours amongst the citizenry. There was the historic 'failure' of governance, lack of genuine patriotism, corruption in all places, insecurity in the Nigerian State. This made Ifeduba (2010:366) to argue that the nation's weaknesses appear to globally outweigh the area of her strength. Such negative behaviour begins to create a gradual wave for change that could be driven by the government or individuals. During the Obasanjo's administration, the then Minister of Information and National Orientation, Mr. Frank Nweke (Jnr.) 'gave birth' to the Heart of Africa Project, which collapsed because it concentrated its image making activities on only what Nigerians are doing abroad. This made Professor Dora Akunyili, the former Minister of Information and National Orientation to come-up with the rebranding Nigeria project in March, 2009. "The project came with a new logo and sloganGood People; Great Nation" and is meant to launder Nigeria's image; or prove that we are not a nation of 140 million fraudsters and cheats" (Onumah, 2011:11). Her idea was to create in the consciousness of Nigerians both at home and abroad the need for change in their ways of doing things from negative to positive, as well as to enhance Nigerian national image abroad. Aregbeshola (2009) wrote that Professor Akunyili's programme intends to start with raising a patriotic spirit in Nigerians at home by selling logo and slogan to them. "Vice President Goodluck Jonathan, who represented the president at the launch, described the campaign as a genuine attempt to re-orientate Nigeria towards believing in themselves once again" (Onumah, 2011:11). The re-branding 
136 Africa's Public Service Delivery \& Performance Review

Nigeria campaign as positive as it was met much societal criticism and resentment because it came at a time Nigerians have much apathy for the government, especially in an era that was characterized with politics about failed state; whether Nigeria was already a failed state or not (in 2009). Akunyili (2010:27) stated that "if nothing at all, the seed of re-branding has sparked debates, dialogues and seminars which have contributed in one way or another to the advancement of the cause". One of the pessimistic opponents to the re-branding project articulated his thought thus:

Isn't this another gimmick to steal money?

What does she want to re-brand?

Is it re-branding Nigeria needs now?

Is Nigeria even a brand?

She just loves publicity and this project will give her plenty.

She is a trouble maker.

We are too hungry for this nonsense.

We have bigger problems.

In fact, Nigeria is too far gone in her corrupt ways for Akunyili to do

anything about it.

Does she think she's still in NAFDAC?

It won't work!

She can make all the noise she wants but this won't work

(Quoted in Egbemode, 2009:56).

The opinion expressed by the writer of the above 'poetic verses' captured some of the general ideas of those who hated the project with obsession. Especially in the phase of the universal truth that Nigeria is a corrupt haven and that millions of Nigerian populace are living below poverty level. But the rhetorical questions of what she wants to re-brand is Nigeria, with the inherent problem highlighted. More still, the open assault of the then number one person, in charge of national orientation was simply criticism taken too far. The argument that the country is too far into the depth and valley of corruption therefore called for a national change, instead of continuous neglect as propagated by the poet. This is because corruption is a violent behaviour that has many manifold effects on the society. The poet's argument that re-branding would not work in 
Nigeria is a proposition that would be tested with time. This is because, as bad as Nigeria is today, the masses are still desirous of change and if the present generation cannot enthrone it, the future generation would not want change to elude them. However, another respondent Emewu (2009:14) stated that "I hear they are re-branding Nigeria. Good project, I must say; if what I heard is right." Ugbomah (2009:40) has argued that "re-branding is a worthy investment".

This article shows the link between the media and the re-branding project. It argued that the mass media is a vehicle that transports the project to the different nooks and crannies where the Nigerian masses are located. It argued further that the chances of effective national re-branding is still slim in the Nigeria of today due to numerous problems such as lack of re-branded leadership, collapsing education sector, corruption, advance fee fraud, national insecurity, poverty etc. The article shows the prospects for national image, peace and security. The inter-connectedness between security and peace on one hand and the re-branding of Nigerian image project is not connected to the fact that every nation building project is only carried out in an environment that is peaceful likewise secure and Secondly the indication that peace has been conceptualized as a continuous developmental process which allows for positive and progressive societal change.

\section{Theoretical Framework}

This article is centred on the functionalist theory of mass media. Merton (1975) shows that theory provides the framework to explain social practices and institutions in terms of the needs of society and individuals. The media functionally promotes every act that would lead to national development in a state. The re-branding campaign is a fundamental political strategy of state-craft, which the media centrally promotes. Bo (2010:213-4) argued that the functionalist theory projects the society and the media as a system of linked parts, each of which makes essential contribution to continuity and

order. McBride (1980:3) while writing on the functional importance of communication to societal transformation stated that: 
138 Africa's Public Service Delivery \& Performance Review

Communication maintains and animates life. It is also the motor and expression of social activity and civilisation. It leads people from instincts to inspiration through variegated processes and systems of enquiry, command and control. It creates a common pool of ideas, strengthens the feelings of togetherness through exchange of messages and translates thoughts into actions, reflecting every emotion and need from the humble task of human survival to supreme manifestations of creativity or destructions. Communication integrates knowledge, organization and power as well as runs a thread linking the earliest memory of man to his noblest aspirations through striving for a better life. As the world has advanced, the task of communication has become ever more complex and subtle to contribute to the liberation of mankind from want, oppression and fear as well as unite it in community and communion, solidarity and understanding (McBride, 1980:3).

Nigeria as a nation needs greater improvement on positive communications in the face of myriads of problems that are running-down the country. She needs the mass media to continually enhance and integrate the positive cultures needed by Nigerians to achieve their noblest aspiration of a re-branded Nigeria that would be a true "Giant of Africa." The populace desires increased liberation from poverty-stricken life, political oppression of the ruling class, and increased solidarity and understanding that would rebrand Nigeria and increase national peace, security as well as the standard of life in the country.

\section{Conceptual Clarification of the term Re-branding}

The idea of improving one's geo-political environment has remained a historic culture of man. Societies and nations engaged in one form of program or another in order to rebrand her geopolitical environment. It must be noted that re-branding Nigerian project is conceived as a perpetual progressive act that is not limited to a given government as the citizenry of a country continually engages in one act or another which is meant to progressively transform their society. Ifeduba (2010:363) wrote that "Nigeria as a global brand has its people as the core-product." The quest for national re-branding is not 
unconnected to the extra-ordinary bastardization of Nigerian national image both at home and abroad. The country has been bedevilled by all manners of societal vices that call for urgent change. "Re-branding is a planned, systemic and sustainable effort to reposition existing brand from what it should be in the minds of the consumers. National re-branding is a planned, systematic and sustained effort to reposition a nation's image and reputation in the mind of its various stakeholders" (Asemah 2010:65). Re-branding is the conscious effort to change the nation building culture of a state for better. The re-branding process of a country is a perpetual process of enhancing the sovereign nature of a state. Ifeduba (2010:363) wrote that "the re-branding or reconfiguring effort should logically be geared towards eliminating corrupt practices and highlighting the nation's unique selling point." Olu (2009:11) wrote that the re-branding "exercise speaks to the image and the substance (of Nigeria), a moral and ethical reawakening, a drive for corporate governance and transparency in public practice." Baker and Hart (2007) documented that brand building is essential for many reasons, amongst which include:

i. To build stable long term demand (of Nigerian products).

ii. To develop a sound basis for further growth and expansion.

iii. To maintain the interests of intermediaries and

iv. To create a reputation as an organization (or a nation) that people will want to develop relationship with.

Consequently, Ifeduba (2010: 368) as well as Baker and Hart (2007) have shown that rebranding is more than image problem but on lack of integrity. In line with the same argument, Obi-Uchendu (2009:88) wrote that "the re-branding tag line: 'Nigeria: Good People, Great Nation' is a good place to start but unfortunately no one would take that seriously until our actions and attitudes reflect how great we can be." Asemah (2010:6970) wrote that the objectives of the re-branding Nigeria project include:

a. Reconnecting Nigerian people with Nigerian nation.

b. Making Nigerians own and be proud of the Nigerian brand.

c. Re-position Nigeria as a modern, democratic, disciplined and accountable nation. 
140 Africa's Public Service Delivery \& Performance Review

d. Making every Nigerian the chief advocate of the Nigerian project

e. Encouraging civic conscientiousness and community participation

f. Changing Nigeria and Nigerians' negative perceptions amongst foreigners and external stakeholders

g. Leveraging on the passion of Nigerians in the Diaspora to make Nigeria more globally competitive.

\section{Mass Media and the Politics of Re-branding}

The Nigerian re-branding project was championed by government officials. Nevertheless, whether the re-branding process was government or the masses-oriented, the mass media remains at the centre of the process. Throughout human civilization, the media have remained a vehicle for the acquisition of power and promotion of social agenda that would help the politicians to maintain legitimacy as well as manipulate power and the society. They achieve it through their agenda-setting role (McCombs \& Shaw 1972:176-187). Wright (1986) wrote that the mass media are organized and operated to implement government's social and political policies. Ironically, one of the ways to attain legitimacy and remain valuable in the dynamics of leadership is to promote social change and re-brand a country's image nationally and internationally.

Bagdikian (1971: Xii-Xiii) has shown that "the world and its inhabitants are what the news media say they are." Marger (2002:445) went on to document that "in modern societies, to publicly communicate views or ideas requires the use of the media." The implication becomes that the government dominates the news content of the media. Their hegemonic influence on the media, especially in Nigeria is not unconnected to Government's large scale ownership of the media networks in the country. The privateowned media firms are equally caught-up in the web of government influence as activities of men-in-authority dominates their reportage. "In modern societies, only government and big business have the resources, money, authority and influence to employ the media regularly and effectively" (Marger, 2002: 445). They use their money and political influence to shape the message content of the media. The government exports their re-branding message through other international multi-media networks. That has been made possible due to the increasing trend towards the convergence of national networks and companies into transnational units (Schiller 1989). Hence, having 
Mass Media and Re-branding Nigeria Project 141

become the centre-piece of media message, they tend to sponsor many waves of programmes, which are aimed at re-branding the country. Government influence and use of the media to preach their re-branding campaign is not only "founded on financial power but on the fact that the media are closely interwoven with government, particularly at the national level. Put simply, the relationship between government and media is symbiotic; neither can function effectively without the other" (Marger, 2002:445). The media depends heavily on the political elites in Nigeria for the information, which forms the core of the re-branding message. While the masses continuously writes on rebranding message, the re-branding news generated from the government often occupied a major theme of the print and electronic media.

Politicians and government officials easily gain access to the mass media simply because they possess media credibility as source of news. Gans (1979) wrote that their accounts of events and policies are more likely to be accepted and thus become part of the news format than accounts and interpretations provided by other sources. Moreover, in gathering information, the media ordinarily follow the path of least resistance; this means relying on official sources for information (Marger 2002:446). Herman and Chomsky (1988:19) have noted that "taking information from sources that may be presumed credible reduces investigative expense, whereas material from sources that are not prima facie credible, or that will elicit criticism and threats, require careful checking and costly research". Postman (1985) wrote that political dialogue, particularly at the national level, is increasingly reduced to creating impressions that would lead to national re-branding and societal development. This process reaches a high point in the orchestration of pseudo-events, that is, carefully scripted and staged events that are designed to create favourable public images but that have little basis in reality (Boorstin, 1961).

"Government elites, however, are equally dependent on the mass media. This dependency stems from their need to employ the media to convey their messages to the public and thus shape and influence public opinion. Political leaders today rarely engage in face to face communication with the masses. Instead, they speak primarily through the electronic media in sound bites and project their images through photo opportunities" (Marger, 2002:446). The politicians that are championing the re-branding 


\section{Africa's Public Service Delivery \& Performance Review}

project would constantly grant interview to the communication elites - editors, journalists and media executives - as a means to project their personal political image, knowing that any event covered by these communication elite has become newsworthy (Cohen \& Young 1973; Epstein 1974; Tuchman 1978).

With ample access of Dora Akunyili and other politicians to the mass media, they were able to place the re-branding campaign in ways "likely to influence their resolution" (Bennet 1988:96). The Nigerian political cycle and its re-branding agenda has "become a caricature drawn out of unrealistic stereotypes, predictable political posture and superficial images" (Bennet 1988:96). This is because the news content offered by many Nigerian politicians does not reflect through news value on national re-branding. Gans (1979: 39-40) has shown that "the values in the news are rarely explicit and must be found between the lines - in what actors and activities are reported or ignored and how they are described."

Regrettably, there is no objectivity in political communications; hence the media message from politicians on re-branding Nigeria project only reflects their individual and collective political goals. Blumler and Gurevitch (2000) have shown that political communication is facing the problem of lack of coherent party-minded social class forcing both the masses and the politicians to be individualistic and sceptical. One cannot deny the fact that the re-branding campaign has been driven more by the individual political charisma of Dora Akunyili and her ally as the re-branding campaign is yet to receive the collective responsibility of those in position of authority. What is obtainable in Nigeria is that the politicians who engage in the re-branding project influence the media, directly or indirectly, in the re-branding campaign to "toe the line" (Gans, 1979). Public information/statistical data are manipulated, distorted and even manufactured as government and politicians use information to further their political goals (Ayedun-Aluma, 2010:126). Even when a few numbers of Nigerians try through the media to resist, criticize or oppose the re-branding strategy, the dominant re-branding political topic is still projected to the audience.

Ironically, a true national rebranding in Nigeria, which is advocated in this work must start with attitudinal change from the masses. It is such massive attitudinal change that would drive the wind of national rebranding. Unfortunately, human security is of vital importance for the re-branding Nigeria project. This is because rebranding is 
championed by those who are alive and it is meant for the living, and not those who have died in conflict. Hence, peace is a vital condition for the rebranding project to start.

\section{Historic Challenges that Militated against Re-branding Lack of Re-branded Leadership}

People in government must understand that re-branding Nigeria should start from the top. There is still a sightless continuum in the relationship between Nigeria and the Nigerian. There is a loud absence of a social contract between government and the people. This is as a result of the dearth in leadership that execute the business of governance with transparency and selflessness. We need true, tested leaders in our country (Otudo, 2009:29). Egbemode (2009:56) wrote that "our leaders have stolen our money and are in fact still stealing as I write this." There is popular opinion amongst the masses that what Nigeria is lacking and truly needs is a re-banded leadership (Olu 2009:11; Thisday 2009: 19; Ifeduba 2010:361-381). A genuine effort at re-branding Nigeria must start with the national leadership of the country. It is this leadership virtue that is lacking in many of the Nigerian leaders. Anger (2007:219) wrote that Nigerian leaders "are supposed to recognize and acknowledge their positions as an avenue to serve the people and not to achieve their selfish goals. This attribute has indeed been lacking among Nigerian leaders and what obtains is that the present so-called democratic leaders coerce their subjects in yielding to the whims of the leader(s)".

Those who question the authenticity of this multi-million naira project understand that at every juncture in our complex history, our leaders cook-up some hogwash, either because they take us for granted or simply for want of what to do. For a country where everything seems to go awry because of the incompetence of its leaders, it is difficult to take the re-branding exercise seriously. Nigerians do not need to be reminded that they are good people or that they live in a great nation. What they want to see is their leaders working for them. They want a leadership that will rekindle hope and harness the country's abundant talent and resources. Nigerians have lost faith in their own security because that state has failed to fulfil its obligation to them (Onumah, 2011:11-12). 
144 Africa's Public Service Delivery \& Performance Review

\section{Collapsing Education Sector}

Nigerian education system is at its lowest ebb (Ani, 2010B: 163-172), hence, making it difficult for any form of sustainable national re-branding process in a modern world that is driven by knowledge economy to be enthroned. Ifedigbo (2010:48) wrote that "education is in shambles in this country and for that we should wail ...We wailed for the classrooms without desks. We wailed for the libraries without books. We wailed for the endless strikes. We wailed for government and criminality of the rich class that have ensured our schools don't work." Mbadiwe (2009:69) asked "how anyone dares talk of re-branding when our educational standards have nose-dived and Benin, Ife, as well as Ibadan (in that order) is the only Nigerian universities that were ranked on the African continent, not to mention world ranking."

\section{Corruption}

Asemah (2010:76) wrote that "corruption has eaten deep into the fabric of most key position holders in Nigeria." Dalhatu (2010:36) stated that "corruption is a societal disease that has eaten deep into the body of Nigerian society. It has been so pervasive and has cut across all aspects of our national life, so much so that people now adore rather than abhor corruption." The quest to show that Nigeria is a corrupt free environment has been handicapped by the realities of everyday life in the country.

Dalhatu (2010:36) went on to argue that "corruption today is a national culture to the extent that those committing it no longer see it as an offence but a way of life." Mega corruption in Nigeria is a business between the Nigerians syndicates and their foreign collaborators. Agbedo (2010:9) wrote that the indictment of Daimler Chrysler AG, makers of Mercedes Benz automobiles, by a United States District Court for violating anti-bribery laws by giving Nigerians and other country's government officials, bribe in order to gain contract is a tip of the iceberg. The company has to pay $\$ 185$ million fine in plea bargain deal for their corrupt deals in Nigeria (Agbedo, 2010:9).

\section{Advance Fee Fraud}

The term advance fee fraud is popularly known as 419 in Nigeria. Ataman (2007:35) wrote that advance fee fraud is a class of fraud usually perpetrated by deliberate distortion and misrepresentation of facts or matters with the aim of deriving financial 
benefits from unsuspecting, greedy, corrupt and gullible individuals. Asemah (2010:74) wrote that "419ners' activities are still very much on in Nigeria, and this has become a serious impediment to the re-branding project." "Our image is tied to our development, not the other way as the minister would want us to believe. Once we harness our resources as a nation and put our house in order, the world will be forced to take note and give us the respect we deserve. They will remember advance fee fraud (419) - if we still have that in our repertoire - but their focus will be on our contribution to the advancement of humankind. As it stands, Nigeria is not a contender" (Onumah, 2011:12). Waziri (2005) opined that fraudsters normally contact their victims by mail. But there are numerous other ways in which these criminal sects carry out their activities. Ataman (2007:35) showed that the costs of advance fee fraud to the economy are numerous. They include:

a. Discourages investments, particularly foreign investment in-flows and inhibits economic growth.

b. Brings loss of confidence in the economies of the countries of the perpetrators.

c. Reduces the confidence of the citizens in the capacity of its government to protect them from fraudsters.

d. Distorts the flow of trade as confidence level falls.

e. Undermines the stability of banks and other financial institutions.

f. Increases inflationary pressures.

g. Makes a country a candidate for listing as a non-cooperating country and territory by the Financial Action Task on Money Laundering and Financial Terrorism.

\section{National Insecurity}

The country is witnessing the continuous growth of "rampant kidnapping, armed robberies and wicked assassins that prowl the states unimpeded" (Daily 
Sun, 2009:3). The Human Rights Watch has revealed that more than 14,800 people were killed in inter-communal political and sectarian violence in Nigeria within the past twelve years. They went on to reveal that the human cost of the violence is very high in Plateau State, where more than 3,800 people have been killed since 2001 and at least 250 killed since December 2010 (see Bashir, 2011:3).

Ani (2010A:155-163) observes that national insecurity is affecting Nigerian human capital development. The climax of the national insecurity in Nigeria that has destroyed not only Nigerian national image, peace and security in the sight of foreigners is the extra-judicial killing of the masses by the Nigerian police. Respected international human rights watchdog, Amnesty International, recently raised alarm on widespread extra-judicial killings by the police in Nigeria. In a report released in Abuja, the organization's Director of African Programme, Erwin Van der Borght decried the increasing impunity of police killings, failure to investigate reported unlawful deaths, lack of independence and impartiality by police investigators as well as weak oversight mechanisms by the force's high command. The report highlighted police's involvement in unlawful killing and torturing of detainees to death, lack of punishment for policemen who kill unlawfully and failure to provide justice or redress for victims (Daily Sun, 2010:16). Dada and Ani (2010A:155-163) argue that the growth of terrorism that is connected to the Nigerian State is affecting the country's national image.

\section{Poverty}

Ogbe (2009:47) wrote that Hillary Clinton, during her visit to Nigeria stated, that "the most immediate source of discontent between Nigeria's wealth and poverty is a failure of governance at the federal, state and local levels." The politicians in their corrupt political culture mainly engage in projects and programmes that help them to re-cycle national wealth. "The case of Nigerians is that of suffering in the midst of plenty. In the face of abundant resources, most Nigerians still live in abject poverty and hunger. Politicians are paid stupendous salaries for doing nothing at the instance of providing 
the ordinary Nigerians with food, job, shelter and other necessities of life" (Asemah, 2010:81). Ani (2011C: 223-237) revealed that the Nigerian political leadership are intensifying the conflict situation in the country due to their excessive looting culture.

\section{Prospects for Improved National Image}

Peace is a multi-dimensional concept. It is a condition sine qua non for the national rebranding process of any country. It is a condition that allows for the rise of every positive move that promotes the nation building process. Ogboji (2010:130) wrote that "there is nothing that endures more than peace and conditions in which peace is achieved." Boutros-Ghali (1995) showed that peace building is the "creation of a new environment" that would enhance national development. It is a collection of these new nation-building environments (that has being both crippled and aborted) that would lay a good foundation for sustainable national re-branding. Peace naturally brings faith and patriotism to the individual masses and by extension the larger society.

The most threatening of the whole re-branding process is the hopelessness and lack of faith in anything done in this sovereign state called Nigeria. The masses inability to show patriotism has not only aborted the ethical behaviours that would have promoted Nigerian national image but it has also constituted in increasing national violent behaviours of all kinds. It is this societal apathy which promotes violence that calls for change in order to enhance national image, peace and security. Ani (2012:140-158) has called for increased peaceful communication in this era of mass violence, conflicts and terrorism. On the other hand, there are a good number of Nigerians including those identified nationally and those neglected at the country's extreme corners that are toiling day and night to improve the Nigerian society. It is these men and women who are the pillars of the future Nigerian brand that would one day be pursued by the majority of Nigerian masses who are already disgruntled with the ways of doing things in this country. "Societal reorientation represents a systematic and virile strive through which desirable qualities such as discipline, honesty, piety, hard work, sacrifice and selflessness can be instilled in our citizens. It entails a firm commitment to putting in place the required institutions and procedures and the pursuit of conduct that overtime will result in a God-fearing, enterprising and cultured society. This is expected to bring about 
positive attitudinal changes in the people; changes that will engender love for the state, foster societal harmony, minimise social menace, develop human resources to their full potential and ensure rapid development and progress while protecting societal norms and values (Shakarau, 2009).

Emewu (2009:14) wrote that "before we re-brand Nigeria and get it right, we should first ask where Nigeria started getting bad from. Where is the engine of Nigeria, from which we could mend it and it gets going again? The engine is the leadership." National re-branding that starts from our leaders would have much multiplier effect on the society than 'media-based' re-branding. Thisday (2009:19) argued that if re-branding starts with our leaders, there would be no need for the re-branding of leaders of tomorrow (as they would naturally become acculturated into the re-branding process). Leadership is the inducement of followers to act in a way that represents societal aspirations. An essential quality or attribute of leadership is virtue. Virtuous behaviours enhance national image, peace and security.

Today, the ability of the Goodluck Jonathan administration to practice their slogan that "the vote of Nigerians will count" through the Professor Atahiru Jega led Independent National Electoral Commission has placed Nigeria on the road to becoming the largest Black effective democracy in the world. Emewu (2009:14) went on to argue that "when you give people leadership, they naturally reciprocate with a change in attitude to their country. There is no nation where the citizens have what they need from government where the morale is low regarding patriotism. We all love Nigeria."

There is need for transformative and ethical education in Nigeria as a basis for national re-branding. Such transformative education system would "pay optimal attention on character building and re-enforcement" Onosode (2006:8). Egbemode (2009:56) prayed that the days may come in Nigeria "when Universities will stop commercializing admission and brilliant students' slots are no longer sold to the emptyheaded children of highest bidders." The Nigerian education system needs to be transformed through the private-public partnership. Normative evaluation of the conduct of all and sundry is vital at every level of Nigerian education, in order to identify and wipe-out those that have institutionalized one form of anti-learning behaviour or another in the system. There is equally the need for the integration of peace education into all level of our education curriculum (see Ani, 2009: 39-49; Ani, 2011A:230-238 \& Ani, 2011B:96-101). 
Ifeduba (2010:361-381) wrote that the nation should "curb corruption and strengthen character in its brands such as sports, graduates, leaders, businessmen and professionals; the success of these individuals would naturally rub off on and polish the image of the nation." Nkwocha (2009:5) wrote that "in Nigeria for example, it becomes imperative in this era of re-branding, re-orientation and anti-corruption war that the society be adequately sensitized... It is time the Nigerian State face reality and re-invents an ingenious way to stop this monster called corruption; otherwise we would all be consumed by it."

There are many ways to promote national image abroad. They include: effective lobbying network, effective diplomacy, enhanced international aids, and grants, etc. However, bringing sovereign states and multinational companies to book whenever they attack the sovereign image of the country is a way to promote the needed positive image of the country.

Sony Corporation faced strong complaint from the Federal Government of Nigeria following their advert on Sony's new "Slim" Play Station 3. The station showed a salesman being asked about the price of a product and the response was that "you can't believe everything you read on the internet; otherwise you will be a Nigerian millionaire by now." The advert presented Nigeria as the epicentre of advance fee fraud and the safe haven for fraudsters. "Nigeria demanded an unconditional apology from Sony Corporation for deliberate negative campaign against the country's image and reputation." Sony apologized for the offence caused by the advert, which they said was not intended for broadcast outside the United States. The apology read thus: "it has come to our attention that a recent TV advertisement from Play station may have offended some members of the Nigerian community" (Said Sony in a statement). We never intended to create a situation that would upset anyone, and we have taken action to immediately remove the advertisement from the air. We apologise to anyone this may have offended" (Nigerian Compass News, 2009:6).

\section{Conclusion and Recommendations}

This article is a historical investigation into the rebrand Nigeria project that was championed by a former Nigerian Minister of Information. Unfortunately, the effort of 
Professor Dora Akunyili to spread the rebranding Nigeria project failed because of a combination of many factors. The masses were largely living in a world characterised by all manners of societal and nation building challenges as against the position of the Nigerian power elite, who were principally enjoying the dividends of democratic offices and high portfolios. Again, the numerous problems highlighted earlier were contributing bottlenecks to the growth of the citizen-driven rebranding culture. Consequently, the quest by Dora Akunyili to context for the senatorial election in Anambra State, which she lost to Senator Chris Ngige finally created the condition that led to the demise of the rebranding Nigeria project. Paradoxically, Akunyili's successor, Labaran Maku, who was the then Minister of State under her practically ensured that the re-branding songs, which he was singing with his former political boss was permanently buried and forgotten as he decided to follow the path of good governance tour around the states of the federation instead of continuing in the journey to re-brand Nigeria. It could be stated that Labaran's negligence of the songs of rebranding Nigeria soon turned the project into one of the numerous and progressively abandoned as well as failed projects in Nigerian political history.

Onumah (2011) has argued that this is "time to reclaim Nigeria." This is achievable only in an atmosphere of peace, where everybody must work collectively towards attaining peace. It is worthy of note that when an individual pilot the plane for national change and re-branding, it is easily criticized and the merits of the projects gradually abandoned; but when a revolutionary movement for change starts, it easily creates a revolutionary spirit that could sometimes give birth to a full-fledged societal ontological change. However, when the train of re-branding and national change is driven relentlessly by the government, it often generates a wave of criticism and gradual support from the citizenry.

It is noteworthy that the re-branding project is a wonderful political initiative. It is a major driver driving Nigeria's national image of transformation amongst the committee of nations. However, in the domestic front, the implementation process has created a paradox. The implication of the paradox created between the politicians' message of rebranding and the societal perception of the process is that what the politicians are saying remains influenced more by their quest for legitimacy, as well as political and social class. Klufio (2011) wrote that the exciting and encouraging concept of nation branding is extremely challenging to execute. The re-branding campaign is yet to 
generate the needed 'mass audience change'. This is not distinct to the fact that "no simple 1-1 relationship exists between content or intent and effects" (Gollin 1988:43). This is because while the politicians could effectively use the media to tell the audience what to think about, they are not effective in telling them how to think of the matter. It is the audience that decides the content analysis and direction they would think of a particular media message.

Finally, Otudo (2009:29) wrote that for Nigeria to attain her re-branding goal, the country should focus on her areas of strength to build an exciting and enduring national brand identity. There is need for increasing priming of re-branding political communications. Priming refers to the changes in the standard that people use in making political choices and judgements (Iyengar \& Kinder 1987). As the re-branding news shifts its attention from one issue to another, governments and political leaders are to be judged on their performances regarding those issues (Marger 2002:451). The rise of new media in Nigeria, which will "put back the public at the centre of its practice must be regarded as a professional challenge facing the profession today" (Matenda 2009:80).

Maxwell (2009:4) has shown that "all the words you speak as a leader mean nothing if your life doesn't back it up." Hence, our political leaders need to engage in normative politics as a road-map to national peace and re-branding. There is need for reformed judicial and education systems as a means to fight corruption and advance fee fraud, before the country would achieve sustainable national re-branding - a form of rebranding that is driven by the masses.

\section{List of References}

- Agbedo, O. 2010. "The Untold Story of the ANAMMCO Scam," The Guardian, Saturday, July 3

- Anger, A. B. 2007. "Leadership and the Crisis of Democracy in Nigeria", African Journal of Indigenous Development, Vol. 3, No. 1\&2, January-December, pp. 214-223. 


\section{Africa's Public Service Delivery \& Performance Review}

- $\quad$ Akunyili, D. 2010. "Selling the Nigerian Brand in 2010", Daily Sun, Wednesday, January

- Ani, K. J. 2012. "Political Violence in Nigeria and Peaceful Political Communication for Sustainable National Democracy" in D. Wilson (Ed.) The Media, Terrorism and Political Communication in Nigeria, Uyo: BSM Resources, pp. 140-158.

- Ani, K. 2011a. "Linking Formal and Informal Peace Education in Nigeria: Constraints and Prospects for Nomadic Teachers", Nigerian Journal of Curriculum Studies, Vol. 18, No. 3. pp. 230-238.

- Ani, K. 2011. "Peace Education for Senior Science Curriculum: problems and Prospects", Journal of Curriculum and Instruction, Vol. 8, No 1. pp. 96-101.

- Ani, K. 2011c. Politics About failed State in Nigeria: Dialectics on the Value of History to Nation Building Challenges, 1960-2010, Enugu: BookFirst

- Ani, K. 2010a "Issues and Challenges of National Security to Human capital Development", Lit Academic Journal: An International multidisciplinary Publication, Vol. 1. No. 2. pp. 155163.

- Ani K 2010b. "Resolving Issues and Challenges in Human Capital Development through Catholic Education Policy" Lit Academic Journal: An International multidisciplinary Publication, Vol. 1. No. 2. pp. 163-172.

- Ani, K, 2009. "Inter-Religious Socialization as a Peace Education Subject for Conflict Management in Nigeria", Maiduguri Journal of Peace, Diplomatic and Development Studies, Vol. 2, No 2. pp. 39-49.

- Aregbeshola, B. 2009. "Re-branding Nigeria Project and Akunyili's Competence" http//www.Nigerians-in-ameica.com/article/325/1/Rebranding-Nigeria-Project-andAkunyili's-Competence/page1.html Posted $18^{\text {th }}$ February, 2009 and retrieved on $4^{\text {th }}$ April, 2011

- Asemah, E. S. 2010. Public Relations and Democracy in Nigeria: A Componential Overview, Jos: Matkol Press

- Ataman, P. 2007. "The Anatomy of Advance Fee Fraud: Forms, Victims and Preventive Measures", Central Bank of Nigeria Publication (Transparency), Volume 1, Number 1, June

- Ayedun-Aluma, V. 2010. "Information Paradigm of Development Communication and Development Problems in Nigeria" The Nigerian Journal of Communication: Journal of the African Council for Communication Education, Nigerian Chapter, Vol. 8 No1. pp. 118-137.

- Bagdikan, B. 1971. The Information Machines, New York: Harper and Row 
Mass Media and Re-branding Nigeria Project 153

- Baker, M. and Hart, S. 2007. Product Strategy and Management (2 ${ }^{\text {nd }}$ Ed.) New York: Prentice-Hall

- Bashir, M. 2011. "Rights Group Says 14,800 People Killed in Violence", Daily Trust, March 29

- Bennet, W. L. 1988. News: The Politics of Illusion, (2 ${ }^{\text {nd }}$ Ed.) New York: Longman

- Blumler, J. G. and Gurevitch, M. 2000. "Rethinking the Study of Political Communication" in Curran, J. and Gurevitch M. (Eds.) Mass Media and Society (3rd Ed.) London: Arnold Group

- Bo, D. 2010. "Reporting in a Bi-cultural Society: Study of Media Reports on Marriage Ceremonies in Tivland," in D. Wilson, (Ed.) Perspectives on Communication and Culture, Uyo: BSM Resource Nig. Ltd, pp. 207-221.

- Boorstin, D. J. 1961. The Image: A Guide to Pseudo-Events in America, New York: Harper and Row

- $\quad$ Boutros-Ghali, B. 1995. An Agenda for Peace, New York: United Nations

- Cohen, S. and Young, J. (Eds.) 1973. The Manufacture of News, London: Constable

- Dada, J. P. and Ani, K. J. 2010 "The Impact of Terrorism on Nigerian National Image" in Dada, J. P., Abdulmumini, S. and Abubakar, M. (Eds.) Peace, Security, human Rights and Development in the 21st Century Volume 2, Kaduna: Pyla-Mak Services Ltd, pp. 317-334

- Daily Sun, 2010. "The Damning Report on Nigeria Police", Wednesday, 6 ${ }^{\text {th }}$

- Daily Sun 2009. "Restore Confidence to South Easterners: Senator Okonkwo Charges Security Agencies", Tuesday, December 22

- Dalhatu, K. 2010. "Legislature's Role in the Fight against Corruption in Nigeria", Daily Sun, Wednesday, January 6

- $\quad$ Egbemode, F. 2009. "Why Can't Akunyili Just Leave Us Alone", Sunday Sun, March 22

- $\quad$ Emewu, I. 2009. "Text Message Re-branding", Saturday Sun, March 28

- $\quad$ Epstein, E. J. 1974. News from Nowhere, New York: Vintage

- Gans, H. J. 1979. Deciding What's News, New York: Pantheon

- Gollin, A. E. 1988. "Media Power: On Closer Inspection, It's Not That Threatening" in Ray Eldon Hiebert and Carol Reuss (Eds.) Impacts of Mass Media, (2 ${ }^{\text {nd }}$ Ed.) New York: Longman 


\section{Africa's Public Service Delivery \& Performance Review}

- Herman, E. S. and Chomsky, N. 1988).Manufacturing Consent: The Political Economy of the Mass Media, New York: Pantheon

- Ifedigbo, S. N. 2010. "Wailing for the Wrong Reasons", Daily Champion, Thursday, January 14

- Ifeduba, E. 2010). "Re-branding Nigerian Students with Codes of Conduct: Analysis of Media Messages, Models and Milestones at Redeemer's University" in Des Wilson (Ed.) Perspectives on Communication and Culture, Uyo: BSM Resources Nig. Ltd, pp. 361-381

- Iyengar, S. and Donald, R. K. 1987. News That Matters: Television and American Opinion, Chicago: University of Chicago Press

- Klufio, C. N. 2011. "More than We Can Chew: The Paradox of Re-branding Africa", http.www.brandchannel.com/images/papers/522-2011-03-klufio.pdf. Posted March 1, 2011 and retrieved on $4^{\text {th }}$ April, 2011

- Marger, M. N. 2002. "The Mass Media as a Power Institution" in Susan J. Ferguson Mapping the Social Landscape: Readings in Sociology, Boston: McGraw-Hill

- Matenda, S. 2009. "Nurturing African Public Spheres: Lessons From the Zimbabwe Presidential Runoff Elections" Journal of Communication and Media Research, Vol. 1, No. 1, April

- Maxwell, J. C. 2009. The Law of the Picture: Outward Reform Begins with Inward Renewal, Abuja; Christian Association of Nigeria and Ibadan: Feyisetan Press

- Mbadiwe, E. 2009. "Nigerian Brand", The Guardian, April 1.

- McBride, S. 1980. Many Voices: One World, New York; UNESCO Press

- McCombs, M. and Shaw, D. 1972. "The Agenda Setting Function of Mass Media", Public Opinion Quarterly 36

- Merton, R. K. 1975. Social Theory and Social Structure, Glencoe, 11: Free Press

- Nigerian Compass News (2009) "Sony to Nigeria: We are Sorry", Wednesday, September 23

- Nkwocha, M. 2009. Systemic Corruption and Control, Jos: Bobb Morgan Ocha and Co

- Obi-Uchendu, E. 2009. "Nigeria: Good People, Great Nation Really?" Thisday, March 22

- Ogbe, V. 2009 "When Hillary Clinton Came Calling", The Spectator, August 14-August 20 
- Ogboji, B. A. 2010. "Art Education Curriculum for Institutionalization of Peace in Nigeria", Nigerian Journal of Curriculum Studies, Vol. 17, No. 3, pp. 128-136

- Olu, T. 2009. "To Rebrand Nigeria", The Nation, March 21

- Onosode, G. 2008. "Education for Public Life". A Paper Delivered on the First Redeemer's University Distinguished Lecture, October 7.

- Onumah, C. 2011. Time to Reclaim Nigeria (Essays 2001-2011), Abuja: African Centre for Media and Information Literacy

- Otudo, C. 2009. "Myths and Realities of Re-branding Nigeria (2)", Thisday, March 22

- Postman, N. 1985. Amusing Ourselves to Death: Public Discourse in the Age of Show Business, New York: Penguin

- Shekarau, I. 2009. "Re-branding Nigeria". An Address by the Governor of Kano State During a Courtesy Call on the Honourable Minister of Information and Communications, Dora Akunyili, April 2

- Shiller, H. I. 1989. Culture: The Corporate Takeover of Public Expression, New York: Oxford University Press

- $\quad$ Thisday (2009) Editorial, February 17

- Tuchman, G. 1978. Making News; New York: Free Press

- Ugbomah, E. 2009. Re-branding is a Worthy Investment", Daily Sun, April 10

- Waziri, R. 2005. Advanced fee Fraud: National Security and Law, Ibadan: Book Builders Education Africa

- Wright, C. R. 1986. Mass Communication: A Sociological Perspective (3 ${ }^{\text {rd }}$ Ed.) New York: Random House

\author{
AUTHOR'S CONTACT \\ ANI, Kelechi Johnmary \\ Department of History and Strategic Studies \\ Federal University Ndufu-Alike, \\ Ikwo, Ebonyi State, Nigeria \\ Email: kani4christ@gmail.com
}

